\title{
Citrulline Metabolism in Normal and Citrullinemic Human Lymphocyte Lines
}

\author{
Elaine B. Spector, ${ }^{1,2}$ Oksana Lockridge, ${ }^{1,3}$ and Arthur D. Bloom ${ }^{1,4}$
}

Received 2 Oct. 1974-Final 18 Feb. 1975

Citrullinemia is one of the five aminoacidurias associated with the KrebsHenseleit urea cycle. A long-term lymphocyte line (UM-2I) derived from a patient with this disease and nine of ten clones of this line were found to have no activity for the enzyme argininosuccinate synthetase $(A S)$, as demonstrated by their inability to grow in medium in which citrulline had been substituted for arginine, by their inability to incorporate arginine- $C^{14}$ derived from citrulline$C^{14}$ into cellular protein, and by direct enzyme assay. One clone had normal or nearly normal argininosuccinate synthetase activity, as demonstrated by the same criteria. Nutritional "variants" able to grow logarithmically in medium containing citrulline were isolated from UM-21 and three clones. The apparent $\mathrm{K}_{\mathrm{m}} S$ of $A S$ for citrulline in UM-21, the ten clones, the variant lines, and a normal line were measured and fell into three groups: $A S$ in $U M-21$ and nine clones had no measurable apparent $\mathrm{K}_{\mathrm{m}}$ for citrulline; AS in the variant cells had apparent $\mathrm{K}_{\mathrm{m}}$ s for citrulline of approximately $20 \mathrm{mM}$; and AS in the normal cell line and one clone had apparent $\mathrm{K}_{\mathrm{m}}$ s for citrulline of $0.2 \mathrm{mM}$. The data suggest that the defect in the citrullinemic cell lines is due to a mutation in the structural gene coding for argininosuccinate synthetase.

KEY WORDS: urea cycle; citrullinemia; human lymphocyte lines.

This research was supported by an NIH Training Grant (5-T01-GM-0071) and an NIH Program Project (P01-GM-15419-07).

1 Department of Human Genetics, University of Michigan Medical School, Ann Arbor, Michigan.

2 Present address: Department of Medicine, University of California at San Diego, Medical School, La Jolla, California.

3 Present address: Department of Pharmacology, University of Michigan Medical School, Ann Arbor, Michigan.

4 Present address: Division of Genetics, Department of Pediatrics, College of Physicians and Surgeons, Columbia University, New York, New York. 


\section{INTRODUCTION}

Citrullinemia is one of the five aminoacidurias associated with the KrebsHenseleit urea cycle. It is thought to be due to a deficiency in the activity of argininosuccinate synthetase (AS; E.C. 6.3.4.5), which catalyzes the conversion of citrulline and aspartic acid to argininosuccinate (Tedesco and Mellman, 1967). Patients with this disease generally have a 50- to 100 -fold elevation in citrulline concentration in the serum, cerebrospinal fluid, and urine, but they often have normal levels of arginine and ornithine, and produce normal amounts of urea (McMurray et al., 1963; Mohyuddin et al., 1967; Morrow et al., 1957). The major manifestations of the disease are protein intolerance, ammonia intoxication leading to convulsions, and mental retardation.

In July 1970, University of Michigan long-term lymphocyte line 21 (UM-21) was established from a 33-year-old mentally retarded male (R. D.) with citrullinemia, citrullinuria, and a history suggestive of at least three episodes of ammonia intoxication during adolescence (Scott-Emuakpor et al., 1972). Of the ten patients with this disease described in the literature, R. D. has the most nearly normal ammonia metabolism. UM-21 has been in continuous culture since its establishment and maintains a stable 46,XY karyotype in $95 \%$ of its cells. In 1971, the parental line was cloned and ten clones were derived (Choi and Bloom, 1970a).

Preliminary studies of UM-21 determined that the citrullinemic defect is demonstrable in long-term lymphocyte cell lines (Spector and Bloom, 1973). In the present report, we describe the citrulline metabolism of the ten clones of UM-21 we studied in order to determine whether there is heterogeneity within and between the clones in their ability to metabolize citrulline. Such heterogeneity would presumably reflect intercellular differences in citrulline metabolism, which would be further proof of genetic variability in human cell populations.

UM-21 and the ten clones were analyzed in several ways. The ability of the cells to grow in medium in which citrulline was substituted for arginine was examined, as was their ability to take up ureido- $\mathrm{C}^{14}$-citrulline into the cell cytoplasm, their ability to incorporate $\mathrm{C}^{14}$ label into trichloroacetic acid (TCA) precipitable protein, and their AS activity. By identifying the metabolic products of citrulline- $\mathrm{C}^{14}$, we have also shown indirectly which of the urea cycle enzymes are present in cultured lymphocytes. Further, nutritional variants different from both citrullinemic and normal cells were derived from the citrullinemic parental lines. The data suggested that the citrullinemic defect in our cells was due to a mutation in the structural gene coding for argininosuccinate synthetase. Lastly, an explanation for the normal urea production observed in this citrullinemic patient is here offered. 


\section{MATERIALS AND METHODS}

\section{Lymphocyte Lines}

The continuously growing lymphocyte cell lines used in these experiments were established by the lysate method (Choi and Bloom, 1970b). The cell lysates used contain the Epstein-Barr virus, which plays a role in the establishment and continuous propagation of the lines (Moore et al., 1967). To date, the virus has not been shown to interfere with host cell metabolism and the expression of biochemical defects in these cells (Choi and Bloom, 1970b; E. B. Spector, unpublished). University of Michigan long-term lymphocyte line 43 (UM-43) was established in January 1974 from a 22-year-old normal male. The citrullinemic line, UM-21, was established in 1970 as described above. In 1971, UM-21 was cloned in microtest plates (Choi and Bloom, $1970 a$ ) and ten clones were isolated.

\section{Growth Medium}

Our lymphocyte lines are routinely maintained in Roswell Park Memorial Institute Medium 1640 (RPMI 1640, Gibco) with $20 \%$ fetal calf serum, plus 60 units of penicillin per milliliter and $0.3 \mathrm{mg}$ of kanomycin per milliliter. This medium normally contains arginine at a concentration of $1.0 \mathrm{~mm}$. In the growth experiments, cells were incubated in two types of media: RPMI with $1.0 \mathrm{~mm}$ arginine $\left(\mathrm{Cit}^{-} \mathrm{Arg}^{+}\right.$) and RPMI with $1.0 \mathrm{mM}$ citrulline substituted for arginine $\left(\mathrm{Cit}^{+} \mathrm{Arg}^{-}\right)$. In toeach type of medium, approximately $0.3 \times 10^{6}$ cells per milliliter from UM-43, UM-21; and UM-21 clones 1 through 10 were inoculated. The cell concentrations were determined every $48 \mathrm{hr}$ in a hemocytometer and viability was determined by trypan blue dye exclusion (Tennant, 1964).

\section{Autoradiography}

UM-43, UM-21, UM-21 variant, and UM-21 clones 1 through 10 were examined for uptake of label derived from citrulline- $\mathrm{C}^{14}$. Approximately $0.5 \times 10^{6}$ cells from each line were incubated for $48 \mathrm{hr}$ in $4 \mathrm{ml}$ of medium containing $0.52 \mu$ moles of ureido-C $\mathrm{C}^{14}$-citrulline (specific activity $7.73 \mathrm{mCi}$ / mmole, New England Nuclear) and $4.0 \mu$ moles of nonradioactive citrulline (Sigma). The citrulline-C $\mathrm{C}^{14}$ was dissolved in Hank's balanced salt solution (HBSS) and stored at $4 \mathrm{C}$. The cells were harvested by washing three times with HBSS. They were then resuspended in $1 \mathrm{ml}$ of fetal calf serum and placed on slides. The slides were stained with carbol fuschin and dipped in Kodak NTB-3 emulsion (Nakagome, 1969). After 8 days of exposure, the 
slides were developed. From each line, 800-1000 cells were analyzed and classified as being heavily labeled ( $>20$ grains per cell), lightly labeled (11-20 grains per cell), or unlabeled ( $0-10$ grains per cell).

\section{Incorporation of $\mathbf{C}^{14}$ Label into Cellular Protein}

Approximately $1.5 \times 10^{6}$ cells from UM-43, UM-21, UM-21 variant, and UM-21 clones 1 through 10 were inoculated into $12 \mathrm{ml}$ of serum-free medium, which was deficient in citrulline and arginine. The cells were incubated for $12 \mathrm{hr}$ at $37 \mathrm{C}$ to starve them for arginine. Cell samples were then divided into three equal parts and placed in three separate test tubes, each containing $4 \mathrm{ml}$ of medium with $0.26 \mu$ moles of ureido- $\mathrm{C}^{14}$-citrulline, $4 \mu \mathrm{moles}$ of nonradioactive citrulline, and $20 \%$ fetal calf serum. The fetal calf serum contained no arginine and only trace amounts of citrulline (R. L. Allen, personal communication). The cells were incubated in this medium for an additional $12 \mathrm{hr}$ at 37 C. One-fourth of each sample was used for protein determination (Lowry et al., 1951). The remainder of the sample was pipetted into a filter apparatus containing GFC glass fiber filter paper (Whatman) and was washed successively with $40 \mathrm{ml}$ each of ice-cold $0.85 \%$ saline, $5 \% \mathrm{TCA}$, and absolute methanol. The filter papers were allowed to air-dry, and were then placed in scintillation vials with $0.5 \mathrm{ml}$ Soluene (Packard) and incubated overnight at $37 \mathrm{C}$. Ten milliliters of nonaqueous scintillation fluid (3.0 liters toluene, $21 \mathrm{~g} \mathrm{PPO}$, and $1.8 \mathrm{~g}$ POPOP) was added and the amount of radioactivity (cpm) in the TCA precipitate was determined in a Packard Tri-Carb scintillation counter, model 3320 , with a $95 \%$ counting efficiency for ${ }^{14} \mathrm{C}$. Activity for each sample was expressed as counts per minute per microgram of protein ( $\mathrm{cpm} / \mu \mathrm{g}$ protein).

\section{Cell Fractionation and Identification of Citrulline-C $\mathrm{C}^{14}$ Metabolites}

Approximately $1 \times 10^{6}$ cells from UM-43, UM-21, UM-21 variant, and UM-21 clone 6 were incubated in $8 \mathrm{ml}$ of medium containing $0.2 \mu$ moles of purified citrulline- $\mathrm{C}^{14}$ for $24 \mathrm{hr}$ at $37 \mathrm{C}$. The cells were spun down and washed once with $0.85 \%$ saline. The cells were harvested and analyzed using a modification of the method of Subramanian et al. (1973). One milliliter of cold $5 \%$ TCA was added to lyse the cells. The TCA-precipitable material was spun down, resuspended in $0.5 \mathrm{ml}$ of $6 \mathrm{M} \mathrm{HCl}$, and hydrolyzed for $24 \mathrm{hr}$ at $105 \mathrm{C}$ in a sealed, evacuated freezing ampule. The incubation medium, the TCAsoluble fraction (cytoplasm) of the cells, and the TCA-precipitable cell protein fraction were analyzed on Dowex 50-X8 (200-400 mesh) (Bio-Rad) columns, $\mathrm{Na}^{+}$or $\mathrm{H}^{+}$form. The resin was prepared by washing it twice for $1 \mathrm{hr}$, each time with $2 \mathrm{M} \mathrm{NaOH}$, and then washing three times with $3 \mathrm{M} \mathrm{HCl}$. 
Fines were removed from the resin by washing several times with deionized water. The resin was packed to a volume of $7 \mathrm{ml}$ in a $10-\mathrm{ml}$ disposable syringe and equilibrated with the first buffer used for each type of column.

Two types of columns were used to separate the possible radioactive products. Arginine- $\mathrm{C}^{14}$ was separated from citrulline- $\mathrm{C}^{14}$, argininosuccinate- $\mathrm{C}^{14}$, and urea- $\mathrm{C}^{14}$ on a $\mathrm{Na}^{+}$column by eluting with $20 \mathrm{ml}$ of 0.116

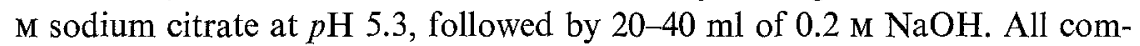
pounds, except the arginine- $\mathrm{C}^{14}$, come through in the first column volume. The arginine- $\mathrm{C}^{14}$ was then eluted with $0.2 \mathrm{M} \mathrm{NaOH}$. Fractions were collected and $1 \mathrm{ml}$ of each was counted in $10 \mathrm{ml}$ of aqueous scintillation fluid ( 2 liters toluene, 1 liter Triton X-100, $8 \mathrm{~g}$ PPO, and $0.2 \mathrm{~g}$ POPOP). The incubation medium, the hydrolyzed TCA precipitate, and the TCA-soluble material were run on this type of column.

Urea- $\mathrm{C}^{14}$ and argininosuccinate- $\mathrm{C}^{14}$ were separated from citrulline- $\mathrm{C}^{14}$ on a Dowex 50-X8 (200-400 mesh) $\mathrm{H}^{+}$column. The sample was eluted with $10 \mathrm{ml}$ of $0.1 \mathrm{M} \mathrm{HCl}, 40 \mathrm{ml}$ of $1.5 \mathrm{M} \mathrm{HCl}$, and $40-60 \mathrm{ml}$ of $6.0 \mathrm{M} \mathrm{HCl}$. Fractions were collected and counted as described above. Urea- $\mathrm{C}^{14}$ and argininosuccinate- $\mathrm{C}^{14}$ eluted in $1.5 \mathrm{~m} \mathrm{HCl}$ and citrulline- $\mathrm{C}^{14}$ in $6 \mathrm{~m} \mathrm{HCl}$. The first column volume containing counts collected from the $\mathrm{Na}^{+}$column to which the TCA-soluble cellular material and the incubation medium had been applied was analyzed on the $\mathrm{H}^{+}$column.

The $\mathrm{H}^{+}$column was also used to purify the citrulline- $\mathrm{C}^{14}$ used in the cell fractionation studies. When purchased commercially, the radioactive citrulline contains a contaminant which behaves like urea- $\mathrm{C}^{14}$ on the columns. In order to remove this contaminant, the powder was dissolved in $5 \mathrm{ml}$ of deionized water. A $0.5-\mathrm{ml}$ sample of the stock solution was placed on a $\mathrm{H}^{+}$ column and eluted as above. The first $10-20 \mathrm{ml}$ of $6 \mathrm{M} \mathrm{HCl}$ elutant was pooled and evaporated. The purified label was resuspended in HBSS and stored at $0 \mathrm{C}$.

\section{Assay for Argininosuccinate Synthetase Activity}

An assay has been developed to measure argininosuccinate synthetase activity in long-term lymphocyte cell lines (Lockridge et al., in preparation). Approximately $0.1 \mathrm{mg}$ of lysed cells was incubated with $5 \mathrm{~mm}$ ATP (Sigma), 0.22 $\mathrm{mm}$ uniformly labeled aspartic acid- $\mathrm{C}^{14}$ (Amersham-Searle, diluted to a specific activity of $20 \mathrm{mCi} /$ mmole with cold aspartate), $10 \mathrm{~mm}$ tris- $\mathrm{HCl}$

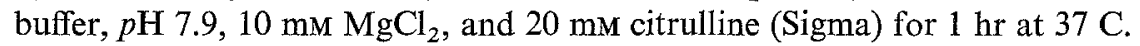
The reaction was stopped by boiling, and the product, argininosuccinate- $\mathrm{C}^{14}$ was allowed to convert to its anhydride form. The product was separated from the remainder of the reaction mixture on a Dowex 1-X8 acetate column by eluting with $3 \mathrm{ml}$ of $0.05 \mathrm{M}$ acetic acid. The entire $3-\mathrm{ml}$ fraction was col- 


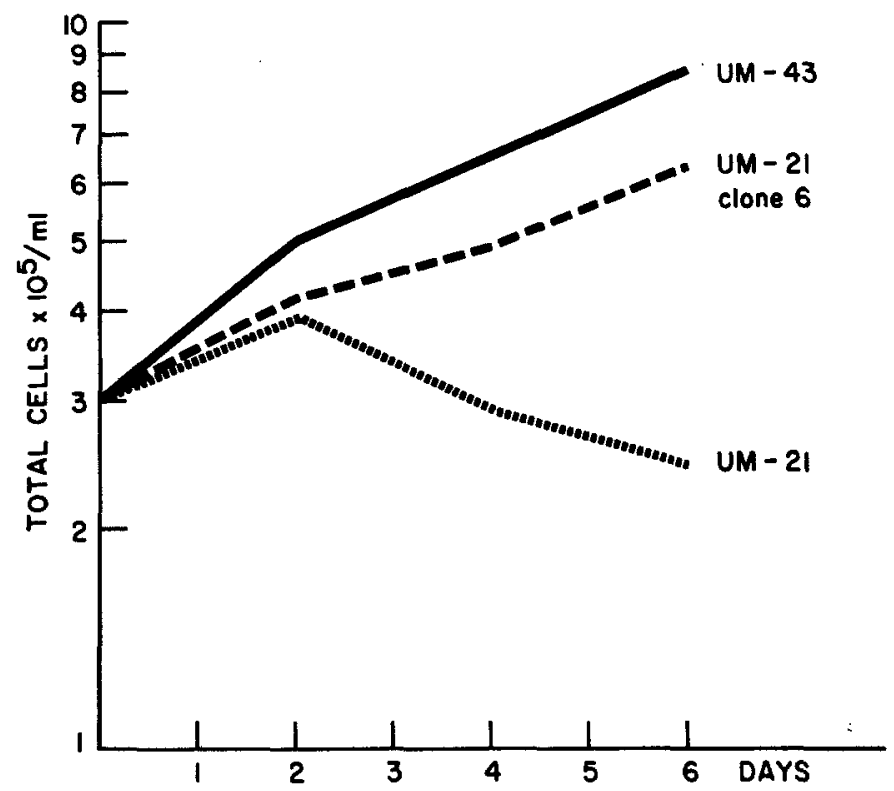

Fig. 1. Growth of UM-43, UM-21, and UM-21 clone 6 in medium containing $1.0 \mathrm{~mm}$ citrulline. Approximately $3.0 \times 10^{5}$ live cells per milliliter were inoculated into 15 or $30 \mathrm{ml} \mathrm{Cit}^{+} \mathrm{Arg}-$ medium. Cells were counted every $48 \mathrm{hr}$ in a hemocytometer and cell viability was determined by trypan blue dye exclusion.

lected in two scintillation vials. Aqueous scintillation fluid was added and the sample counted.

\section{RESULTS}

\section{Growth Curves}

All cells showed normal logarithmic growth in RPMI $\mathrm{Cit}^{-} \mathrm{Arg}^{+}$medium, reaching cell densities of $1 \times 10^{6}$ cells per milliliter. Cells from UM-43 were also able to grow logarithmically in RPMI $\mathrm{Cit}^{+} \mathrm{Arg}^{-}$medium, while cells from UM-21 and nine of the clones did not grow exponentially in the medium (Fig. 1). However, cell densities of $0.15-0.2 \times 10^{6}$ viable cells per milliliter were maintained in cultures of several clones and the UM-21 parental line. After incubation in the $\mathrm{Cit}^{+} \mathrm{Arg}^{-}$medium for 1-2 months, the cells in some of the cultures began to increase in number. UM-21 parental line and three clones (clones 2, 3, and 5) yielded cells that were able to grow in $\mathrm{Cit}^{+} \mathrm{Arg}^{-}$ medium and have been maintained in this medium for over 1 year; four other clones (clones $1,4,9$, and 10 ) yielded cells able to grow in citrulline briefly 
that died out after 2-3 months; and two clones (clones 7 and 8) never yielded cells able to grow in $\mathrm{Cit}^{+} \mathrm{Arg}^{-}$medium. Those cells isolated from UM-21 parent and clones 2,3, and 5 able to utilize citrulline for growth were different from the parental cells from which they were isolated and were referred to as "variant" cells. One clone, clone 6 , was able to grow logarithmically in $\mathrm{Cit}^{+}$ $\mathrm{Arg}^{-}$medium like the normal UM-43 cells (Fig. 1).

\section{Incorporation of $\mathbf{C}^{14}$ Label into Cellular Protein}

Autoradiography was used to demonstrate the incorporation of the $\mathrm{C}^{14}$ label derived from citrulline- $\mathrm{C}^{14}$ into cellular protein (Table I). $\mathrm{C}^{14}$ label in free pools of citrulline and in asparaginyl tRNA was washed out of the cells when they were stained with carbol fuschin. UM-43 had $87 \%$ of its cells heavily labeled. UM-21 and nine clones had no labeled cells. UM-21 variant and UM-21 clone 6 showed a labeling pattern somewhat different from that of UM-43. The UM-21 variant line had $37 \%$ of cells with no label, $39 \%$ with light label, and $24 \%$ with heavy label. Clone 6 had $6 \%$ of cells with no label, $22 \%$ with light label, and $72 \%$ with heavy label.

Studies of the extent of incorporation of $\mathrm{C}^{14}$ label derived from ureido$\mathrm{C}^{14}$-citrulline into TCA-precipitable cellular protein gave results similar to the autoradiography (Table II). The experiments were done in four groups, each group consisting of three citrullinemic cultures and one control culture, UM-43. The numbers represent the averages of triplicate samples. A Dunnett's $t$ test was used to test for significant differences between the mean activities of the mutant cultures and the mean activity of the control culture in each experimental group (Steel and Torrie, 1960). The tests were done using the logarithms of the activities, which equalizes the variances of the small and large numbers and normalizes the distribution of the activities for

Table I. Incorporation of $\mathrm{C}^{14}$ Label Derived from Citrulline-C ${ }^{14}$, into Normal (UM-43) and Mutant (UM-21) Human Lymphocyte Lines, as Visualized by Autoradiography

\begin{tabular}{lccc}
\hline & \multicolumn{3}{c}{$\begin{array}{c}\text { Percent of cells containing specified } \\
\text { number of silver grains }\end{array}$} \\
\cline { 2 - 4 } \multicolumn{1}{c}{ Cell type } & 20 & $11-20$ & $0-10$ \\
\hline UM-43 (normal) & 87 & 12 & 1 \\
UM-21 (citrullinemic) & 0 & 0 & 100 \\
UM-21 (9 clones) & 0 & 0 & 100 \\
UM-21 (variant) & 24 & 39 & 37 \\
UM-21 (clone 6) & 72 & 22 & 6 \\
& & & \\
\hline
\end{tabular}


Table II. Total Radioactivity Incorporated into Cell Protein of Human Lymphocyte Lines Grown in Citrulline-C ${ }^{14}$ for $12 \mathrm{hr}$

\begin{tabular}{|c|c|c|c|}
\hline \multirow[b]{2}{*}{ Experiment } & \multirow[b]{2}{*}{ Cell line } & \multicolumn{2}{|c|}{$\begin{array}{c}\text { Activity } \\
(\mathrm{cpm} / \mu \mathrm{g} \text { protein) }\end{array}$} \\
\hline & & Average & Range \\
\hline I & $\begin{array}{l}\text { Clone } 1 \\
\text { Clone } 2 \\
\text { Clone } 3 \\
\text { UM-43 }\end{array}$ & $\begin{array}{r}48 \\
98 \\
32 \\
116\end{array}$ & $\begin{array}{l}(27-70) \\
(88-119) \\
(11-43) \\
(99-148)\end{array}$ \\
\hline II & $\begin{array}{l}\text { Clone } 4 \\
\text { Clone } 5 \\
\text { Clone } 6 \\
\text { UM-43 }\end{array}$ & $\begin{array}{r}89 \\
12 \\
106 \\
289\end{array}$ & $\begin{array}{c}(70-125) \\
(9-16) \\
(80-142) \\
(154-355)\end{array}$ \\
\hline III & $\begin{array}{l}\text { Clone } 7 \\
\text { Clone } 8 \\
\text { Clone } 9 \\
\text { UM-43 }\end{array}$ & $\begin{array}{r}20 \\
3 \\
4 \\
162\end{array}$ & $\begin{array}{c}(5-36) \\
(2-4) \\
(2-7) \\
(140-193)\end{array}$ \\
\hline IV & $\begin{array}{l}\text { Clone } 10 \\
\text { UM-21 } \\
\text { UM-21 variant } \\
\text { UM-43 }\end{array}$ & $\begin{array}{r}18 \\
6 \\
43 \\
294\end{array}$ & $\begin{array}{c}(4-45) \\
(3-9) \\
(20-72) \\
(258-346)\end{array}$ \\
\hline
\end{tabular}

the control and citrullinemic lines, thereby eliminating the effects of logarithmic cell growth. Cells from clones 2, 6, and 7 and UM-21 variant had activities not significantly different from that of the UM-43 normal control $(p<0.05)$.

\section{Cell Fractionation and Identification of Citrulline- $\mathrm{C}^{14}$ Metabolites}

Analysis of protein hydrolysates from UM-43, UM-21, UM-21 variant, and UM-21 clone 6 on Dowex $50-\mathrm{X} 8 \mathrm{Na}^{+}$columns demonstrated that the radioactive material seen on autoradiography and in the TCA-precipitable material was arginine- $\mathrm{C}^{14}$. No other radioactive products were detected in the hydrolyzed protein. Over $24 \mathrm{hr}$, UM-43 incorporated an average of 1.39 nmoles of arginine- $\mathrm{C}^{14}$ into protein while UM-21 incorporated no radioactivity into cellular protein. UM-21 variant and UM-21 clone 6 incorporated 0.04 and 0.55 nmoles of arginine- $\mathrm{C}^{14}$, respectively (Table III).

The TCA-soluble cell material was analyzed for pools of free citrulline$\mathrm{C}^{14}$, argininosuccinate- $\mathrm{C}^{14}$, arginine- $\mathrm{C}^{14}$, and urea- $\mathrm{C}^{14}$. After running the samples on both $\mathrm{Na}^{+}$and $\mathrm{H}^{+}$Dowex $50-\mathrm{X} 8$ columns, it was found that all of the radioactive material in the TCA-soluble fraction was citrulline- $\mathrm{C}^{14}$. It is not possible at this time to determine if the citrulline- $\mathrm{C}^{14}$ found in this 
Table III. Amount of Arginine-C ${ }^{14}$ Derived from Citrulline-C $\mathrm{C}^{\mathbf{1 4}}$ Incorporated into TCAPrecipitable Cell Protein of Long-Term Lymphocyte Lines in Cell Fractionation Experiment

\begin{tabular}{lc}
\hline \multicolumn{1}{c}{ Cell line } & $\begin{array}{c}\text { Arg-C } \\
\text { (nmoles) }\end{array}$ \\
\hline UM-21 & 0 \\
UM-21 variant & 0.04 \\
UM-21 clone 6 & 0.55 \\
UM-43 & 1.39 \\
\hline
\end{tabular}

Table IV. Apparent $K_{m}$ of Argininosuccinate Synthetase for Citrulline in Citrullinemic (UM-21) and Normal (UM-43) Long-Term Lymphocyte Lines

\begin{tabular}{|c|c|c|}
\hline Line & Medium & $K_{m}(\mathrm{mM})$ \\
\hline UM-21 & $\mathrm{Cit}^{-} \mathrm{Arg}^{+}$ & $-a$ \\
\hline $\mathrm{Um}-21$ variant & $\mathrm{Cit}^{+} \mathrm{Arg}^{-}$ & $26^{b}$ \\
\hline Clone 1 & $\mathrm{Cit}^{-\mathrm{Arg}^{+}}$ & $\ldots^{a}$ \\
\hline Clone 2 & $\mathrm{Cit}^{-} \mathrm{Arg}^{+}$ & $\ldots^{a}$ \\
\hline Clone 2 variant & $\mathrm{Cit}^{+} \mathrm{Arg}^{-}$ & $19^{b}$ \\
\hline Clone 3 & $\mathrm{Cit}^{-} \mathrm{Arg}^{+}$ & $-a$ \\
\hline Clone 3 variant & $\mathrm{Cit}^{+} \mathrm{Arg}-$ & $13^{b}$ \\
\hline Clone 4 & $\mathrm{Cit}{ }^{-} \mathrm{Arg}^{+}$ & —a \\
\hline Clone 5 & $\mathrm{Cit}-\mathrm{Arg}^{+}$ & $\ldots$ \\
\hline Clone 5 variant & $\mathrm{Cit}^{+} \mathrm{Arg}^{-}$ & $26^{b}$ \\
\hline Clone 6 & $\mathrm{Cit}^{-} \mathrm{Arg}^{+}$ & $0.2^{c}$ \\
\hline Clone 6 & $\mathrm{Cit}^{+} \mathrm{Arg}^{-}$ & $0.2^{c}$ \\
\hline Clone 7 & $\mathrm{Cit}-\mathrm{Arg}^{+}$ & $-a$ \\
\hline Clone 8 & $\mathrm{Cit}^{-} \mathrm{Arg}^{+}$ & - $^{a}$ \\
\hline Clone 9 & $\mathrm{Cit}-\mathrm{Arg}^{+}$ & $\ldots a$ \\
\hline Clone 10 & $\mathrm{Cit}-\mathrm{Arg}^{+}$ & $\ldots^{a}$ \\
\hline UM-43 & $\mathrm{Cit}^{-} \mathrm{Arg}^{+}$ & $0.2^{c}$ \\
\hline UM-43 & $\mathrm{Cit}^{+} \mathrm{Arg}-$ & $0.2^{c}$ \\
\hline
\end{tabular}

a Not detectable.

${ }^{b}$ The concentrations of citrulline used ranged from 5 to $300 \mathrm{~mm}$. The apparent $K_{m}$ of AS for citrulline was estimated from a Lineweaver-Burk plot.

$c$ The concentrations of citrulline used ranged from 0.1 to $20 \mathrm{~mm}$. The apparent $K_{m}$ of AS for citrulline was estimated using a Lineweaver-Burk plot. 
fraction was in the cell cytoplasm or was trapped in the interstitial water between the cells during centrifugation.

The medium in which the cells were growing was also analyzed for the presence of citrulline- $\mathrm{C}^{14}$, argininosuccinate- $\mathrm{C}^{14}$, arginine- $\mathrm{C}^{14}$, and urea- $\mathrm{C}^{14}$. Only unmetabolized citrulline- $\mathrm{C}^{14}$ was found.

\section{Enzyme Assays}

Assays done on UM-43, UM-21 variant, and UM-21 clones 1 through 10 growing in $\mathrm{Cit}^{-} \mathrm{Arg}^{+}$medium showed that only UM-43 and UM-21 clone 6 had detectable AS activities (Table IV). The apparent $K_{m}$ of AS for citrulline was measured in all 13 lines growing in $\mathrm{Cit}^{-} \mathrm{Arg}^{+}$medium and in all lines derived from UM-21 parent and UM-21 clones 2, 3, 5, and 6 growing in $\mathrm{Cit}^{+} \mathrm{Arg}^{-}$medium. The AS in the lines fell into three groups: AS with no measurable apparent $K_{m}$ for citrulline, AS with an apparent $K_{m}$ for citrulline of approximately $20 \mathrm{mM}$, and AS with an apparent $K_{m}$ for citrulline of 0.2 mM. UM-21 and nine of the clones growing in $\mathrm{Cit}^{-} \mathrm{Arg}^{+}$medium had no measurable AS activity at concentrations of citrulline up to $0.3 \mathrm{M}$ in the assay mixture; therefore, the apparent $K_{m}$ of AS for citrulline in these lines was unmeasurable. AS in UM-43 and UM-21 clone 6 growing in both $\mathrm{Cit}^{+} \mathrm{Arg}^{-}$ medium and $\mathrm{Cit}^{-} \mathrm{Arg}^{+}$medium had similar apparent $K_{m}$ s for citrulline of $0.2 \mathrm{~mm}$. The apparent $K_{m} \mathrm{~s}$ of AS for citrulline in the variant cells derived from UM-21 parent and clones 2, 3, and 5 growing in $\mathrm{Cit}^{+} \mathrm{Arg}^{-}$medium were approximately $20 \mathrm{mM}$.

\section{DISCUSSION}

UM-21 has essentially no AS activity, as shown by its inability to grow logarithmically in $\mathrm{Cit}^{+} \mathrm{Arg}^{-}$medium, by its inability to take up labeled citrulline on autoradiography, and by enzyme assay. Under long-term selection in medium containing citrulline, a variant line arose that could utilize citrulline for growth. This "variant" has significant AS activity, as demonstrated by its ability to grow in $\mathrm{Cit}^{+} \mathrm{Arg}^{-}$medium, to take up labeled citrulline on autoradiography, and to convert labeled citrulline to arginine incorporated into protein. It also has detectable AS activity with a measurable apparent $K_{m}$ for citrulline.

The ten clones of UM-21 seem to be heterogeneous in their ability to metabolize citrulline. Clone 6 is very different from the other clones of $\mathrm{UM}-21$ in that it has essentially normal AS activity. It can grow exponentially in $\mathrm{Cit}^{+} \mathrm{Arg}^{-}$medium, it takes up and incorporates approximately the same amount of citrulline- $\mathrm{C}^{14}$ into arginine in protein as the normal cells, and its AS has the same apparent $K_{m}$ for citrulline as AS in normal cells. Three 
clones $(2,3$, and 5) gave rise to lines which were able to utilize citrulline for growth after a 1- to 2-month incubation in $\mathrm{Cit}^{+} \mathrm{Arg}^{-}$medium. The apparent $K_{m} \mathrm{~s}$ of AS for citrulline in these variant lines are $13-26 \mathrm{mM}$, as opposed to no measurable apparent $K_{m}$ of AS for citrulline in the parental clones from which they were derived. The remaining six clones died out completely in $\mathrm{Cit}^{+} \mathrm{Arg}^{-}$medium and did not yield lines able to utilize citrulline for growth. Two of these six clones never gave rise to variant cells, while four clones gave rise to variant cells that remained viable only for $2-3$ months. Three classes of clones were found then: six clones which had no cells with AS activity, three clones which had no AS activity but which produced cells capable of utilizing citrulline for growth when incubated in $\mathrm{Cit}^{+} \mathrm{Arg}^{-}$medium, and one clone, clone 6, which had normal or nearly normal AS activity.

Determination of the origin of the variant cells selected from the UM-21 parental line and clones 2,3 , and 5 poses a very interesting problem. These variant cells could be the result of an entire cell population's adapting to citrulline in the growth medium over a period of 1 month. Alternatively, they could have originated from a few cells which had mutated from $\mathrm{AS}^{-}$ to $\mathrm{AS}^{+}$in the parental population and were then selected for in the $\mathrm{Cit}^{+} \mathrm{Arg}^{-}$ medium.

Jacoby (1974) found that long-term lymphocyte lines derived from various donors with no defects in urea cycle enzymes exhibited a lag of $24 \mathrm{hr}$ to 3 weeks before exponential growth began when transferred from medium containing arginine to medium containing citrulline. Lines which adapted within 2-3 days after being transferred to citrulline seemed to have been exhibiting a uniform adaptation of the entire cell population. The lag time was consistent within lines and their clones when tested several times. The lines also had the same cloning efficiency in both arginine-containing and citrulline-containing growth medium, although it took somewhat longer for clones to appear in citrulline-containing medium. The adaptation was accompanied by a significant increase in the AS activity. Jacoby suggested that the short lag period found in some lines and the consistency of the length of the lag period within lines and their clones argued for adaptation of the whole cell population to citrulline as opposed to selection of mutant cells able to utilize citrulline for growth in the original cell population.

The mutant hypothesis is supported by studies of the enzyme asparagine synthetase in a variety of tumor cell lines including Jensen sarcoma cells, Gardner's lymphosarcoma cells, Walker 256 carcinosarcoma cells, and mouse leukemia L5178Y cells (Wriston and Yellin, 1972). These cells were all sensitive to asparaginase and required asparagine for growth because they lacked asparagine synthetase activity. When the cells were placed in medium containing no asparagine, their number declined rapidly for 10 days and then the cells began to multiply and eventually entered a logarithmic growth cycle. 
These cells no longer required asparagine for growth and have been shown to have asparagine synthetase activity. Using Jensen sarcoma cells, Patterson. et al. (1969) determined that two cell populations were present originally. They noted that, although the majority of the cells were dying, the uptake of thymidine- $\mathrm{H}^{3}$ and the number of cells in mitosis increased daily. Extrapolation of the growth curve from the time when the cells began to increase in number to zero time showed a cell doubling time of $36 \mathrm{hr}$ for approximately 100 cells able to grow without asparagine present in the $1 \times 10^{6}$ cells originally seeded. Cloning experiments further supported the hypothesis that the variant cells preexisted in the parental population and were not a result of adaptation of the entire cell population to the lack of asparagine in the medium. Other cloning experiments have shown that almost all tumor cell lines and their clones can eventually give rise to cells able to grow without asparagine. Morrow (1971) and Summers and Handschumacher (1973) used a LuriaDelbrïck fluctuation analysis to provide statistical evidence that cells with asparagine synthetase activity preexisted in the Walker 256 rat carcinosarcoma lines and the L5178Y mouse leukemia line. In both investigations, it was found that the cells able to grow without asparagine preexisted in the tumor cell population and therefore were not induced by growth in asparagine-deficient medium.

The situation with our cell lines is similar to that in the tumor cells in that we are looking for the appearance of cells with activity for an enzyme in a population of cells devoid of it ( $\mathrm{AS}^{-} \rightarrow \mathrm{AS}^{+}$events). Cells with AS activity can be isolated from the parental line and three of nine clones. One clone, clone 6, isolated from the parental line has normal AS activity and can grow equally well in $\mathrm{Cit}^{-} \mathrm{Arg}^{+}$medium or $\mathrm{Cit}^{+} \mathrm{Arg}^{-}$medium. The cells with AS activity are stable and retain their ability to grow in $\mathrm{Cit}^{+} \mathrm{Arg}^{-}$ medium. It took 4-8 weeks to select for cells able to grow without exogenous arginine. This may be due to the fact that the frequency of $\mathrm{AS}^{+}$cells was lower than the 1 in $10^{4}$ that was found in the Jensen sarcoma cells. The striking similarity between our results and those found with asparagine synthetase in the tumor cell lines strongly suggests that the variant cells we isolated originated as spontaneous mutations from $\mathrm{AS}^{-}$to $\mathrm{AS}^{+}$. In addition, if the variant cells arose by adaptation or activation of argininosuccinate synthetase, one would expect the apparent $K_{m}$ of AS for citrulline to be the same in the adapted variant cells as it is in normal UM-43 cells. In this case, the apparent $K_{m}$ of AS for citrulline in the variant cells was 100 times greater than in the normal cells. In order to determine specifically if the $\mathrm{AS}^{+}$variant cells that were selected were produced by adaptation to citrulline or by mutation, a fluctuation analysis should be done on the parental line and the clones.

If mutations from $\mathrm{AS}^{-}$to $\mathrm{AS}^{+}$occur in vitro, as they seem to have in 
some clones of UM-21, they might also occur in vivo. It is possible that R. D. himself is a mosaic composed largely of cells having no AS activity but with a small population of cells that do have activity. The UM-21 parental line might have been established from a heterogenous population of cells, with the UM-21 variant cells representing the subpopulation of cells with AS activity. If R. D. is in fact a biochemical mosaic, it would explain his ability to tolerate a normal protein intake and to synthesize urea, without proposal of the existence of an alternate urea-synthesizing pathway as others have done (Scott-Emuakpor et al., 1972).

The cell fractionation studies give some information about which enzymes of the urea cycle are present in long-term lymphocyte lines. The results of these studies demonstrated that normal lymphocytes (UM-43), UM-21 variant, and UM-21 clone 6 have argininosuccinate synthetase and argininosuccinate lyase activity since they were capable of converting citrulline- $\mathrm{C}^{14}$ to arginine-C ${ }^{14}$. UM-21 did not have this capability, since no labeled arginine could be found in its protein fraction. No urea- $\mathrm{C}^{14}$ was found in any of the cell fractions examined, indicating that there was no detectable arginase activity under the conditions of the experiment.

Some information concerning the nature of the defect in this citrullinemic line can be deduced from these experiments. The defect could be due to a deletion of a structural gene coding for the enzyme or a regulatory protein, to a defect in the transportation of citrulline across the cell membrane, to a point mutation in the gene coding for the enzyme protein leading to a loss of activity and/or instability of the enzyme, or to a point mutation in a regulatory gene leading to decreased synthesis or increased degradation of a normal enzyme protein.

The existence of cells with AS activity such as the variant cells and clone 6 cells strongly suggests that the mutation is not due to a deletion of a structural or regulatory gene, whether the $\mathrm{AS}^{+}$cells were preexisting or arose by mutation.

The defect is probably not in the transport of citrulline across the cell membrane, although further studies would have to be done to rule this out completely.

The data suggest that the citrullinemic defect is due to a mutation in a regulatory gene or in the structural gene coding for AS. Other investigators have used differences in physical properties between enzymes isolated from normal cells and enzymes isolated from variant cells as evidence of a mutation in a structural gene leading to an altered protein product. The criteria that have been used include heat lability (Chasin et al., 1974; Sharp et al., 1973), sensitivity to inhibitors (Albrecht et al., 1972; Chan et al., 1972), immunological cross-reactivity (Beaudet et al., 1973), and kinetic properties (Sharp et al., 1973). The fact that the apparent $K_{m} \mathrm{~s}$ of AS for citrulline in the variant 
cells selected from UM-21 parental line and in clones 2, 3, and 5 are different from the apparent $K_{m}$ of AS for citrulline in normal cells (UM-43) and the fact that AS in clone 6 has an apparent $K_{m}$ for citrulline which is different from that of the variant cells strongly suggest the mutation present in UM-21 is in the structural gene coding for AS. If the mutation in UM-21 were in a regulatory gene, then the second mutation, present in the variant cells and restoring enzyme activity, would probably be in the regulatory gene or in some gene involved in its translation. Under these conditions, AS in the variant cells should have the same apparent $K_{m}$ for citrulline as AS in normal cells. An antibody to human AS that cross-reacts with AS from mutant cells would help to distinguish between the two alternatives. By precipitating the AS with the antibody, one could determine how much enzyme protein is present and whether or not it is active. If there is a small amount of active enzyme present in the UM-21 cells, then one could presume a regulatory gene mutation. Alternatively, if there are normal amounts of an inactive protein present, one may then assume that the basic defect is a mutation in the enzyme protein leading to a change in the active site, with a consequent loss of activity.

\section{REFERENCES}

Albrecht, A. M., Biedler, J. L., and Hutchinson, D. J. (1972). Two different species of dihydrofolate reductase in mammalian cells differentially resistant to amethopterin and methosquin. Cancer Res. 32:1539.

Beaudet, A. L., Roufa, D. J., and Caskey, C. T. (1973). Mutations affecting the structure of hypoxanthine: guanine phosphoribosyl transferase in cultured Chinese hamster cells. Proc. Natl, Acad. Sci. 70:320.

Chan, V. L., Whitmore, G. F., and Siminovitch, L. (1972). Mammalian cells with altered forms of RNA polymerase II. Proc. Natl. Acad. Sci. 69:3119.

Chasin, L. A., Feldman, A., Konstam, M., and Urlaub, G. (1974). Reversion of a Chinese hamster cell auxotrophic mutant. Proc. Natl. Acad. Sci. 71:718.

Choi, K. W., and Bloom, A. D. (1970a). Cloning human lymphocytes in vitro. Nature 227:171.

Choi, K. W., and Bloom, A. D. (1970b). Biochemically marked lymphocytoid lines: Establishment of Lesch-Nyhan cells. Science 179:89.

Jacoby, L. B. (1974). Adaptation of cultured human lymphoblasts to growth in citrulline. Exp. Cell Res. 84:167.

Lowry, O. H., Rosebrough, N. J., Farr, A. L., and Randall, R. J. (1951). Protein measurement with the Folin phenol reagent. J. Biol. Chem. 193:265.

McMurray, W. C., Rathbun, J. C., Mohyuddin, F., and Koegler, S. J. (1963). Citrullinemia. Pediatrics 32:347.

Mohyuddin, F., Rathbun, J. C., and McMurray, W. C. (1967). Studies on amino acid metabolism in citrullinuria. Am. J. Dis. Child. 113:152.

Moore, G. E., Gerner, R. E., and Franklin, H. A. (1967). Culture of normal human leukocytes. J. Am. Med. Assoc. 199:87.

Morrow, G., Barness, L. A., and Efron, M. L. (1967). Citrullinemia with defective urea production. Pediatrics $40: 565$.

Morrow, J. (1971). Mutation rate from asparagine requirement to asparagine non-requirement. J. Cell. Physiol. 77:423.

Nakagome, Y. (1969). DNA replication studies of human D-group chromosomes in satellite associations. Cytogenetics 8:296. 
Patterson, M. K., Jr., Maxwell, M. D., and Conway, E. (1969). Studies on the asparagine requirement of the Jensen sarcoma and the derivation of its nutritional variant. Cancer Res. 29:296.

Schimke, R. T. (1964). Enzymes of arginine metabolism in mammalian cell culture. I. Repression of argininosuccinate synthetase and argininosuccinase. J. Biol. Chem. 239:136.

Scott-Emuakpor, A., Higgins, J. V., and Kohrman, A. F. (1972). Citrullinemia: A new case, with implications concerning adaptation to defective urea synthesis. Pediat. Res. 6:626.

Sharp, J. D., Capecchi, N. E., and Capecchi, M. R. (1973). Altered enzymes in drugresistant variants of mammalian tissue culture cells. Proc. Natl. Acad. Sci. 70:3145.

Spector, E. B., and Bloom, A. D. (1973). Citrullinemic lymphocytes in long term culture. Pediat. Res. 7:700.

Steel, R. G. D., and Torrie, J. H. (1960). Principles and Procedures of Statistics, McGrawHill, New York.

Subramanian, K. N., Weiss, R. L., and Davis, R. H. (1973). The use of external, biosynthetic and organellar arginine in Neurospora. J. Bacteriol. 115:284.

Summers, W. P., and Handschumacher, R. E. (1973). The rate of mutation of L5178Y asparagine-dependent mouse leukemia cells to asparagine independence and its biological consequences. Cancer Res. 33: 1775.

Tedesco, T. A., and Mellman, W. J. (1967). Argininosuccinate synthetase activity and citrulline metabolism in cells cultured from a citrullinemic subject. Proc. Natl. Acad. Sci. 57:829.

Tennant, J. R. (1964). Evaluation of the trypan blue technique for determination of cell viability. Transplantation 2:685.

Wriston, J. C., Jr., and Yellin, T. O. (1972). L-Asparaginase: A review. Advan. Enzymol. $37: 185$. 